Original Research Article

\title{
Preclinical study comparing the antidotal effect of clonidine with atropine for the treatment of acute malathion poisoning in the albino rats
}

\author{
Suresha K. R. ${ }^{1}$, , SantoshKumar M. ${ }^{2}$, Nagashayana $^{3}$
}

\begin{abstract}
${ }^{1}$ Department of Pharmacology Akash Institute of Medical Sciences and Research Centre Devanahalli Bangalore 562110, Karnataka, India ${ }^{2}$ Department of Pharmacology JJM Medical College Davangere, Karnataka, India ${ }^{3}$ Department of Medical Affairs, Navya Technologies Infantry road Bangalore, Karnataka, India
\end{abstract}

Received: 22 October 2016

Revised: 25 November 2016

Accepted: 13 December 2016

*Correspondence to:

Dr. Suresha K. R.,

Email:

drsuresh_pharmac@ rediffmail. com

Copyright: () the author(s), publisher and licensee Medip Academy. This is an openaccess article distributed under the terms of the Creative Commons Attribution NonCommercial License, which permits unrestricted noncommercial use, distribution, and reproduction in any medium, provided the original work is properly cited.

\begin{abstract}
Background: In developing countries 2-3 million people are acutely poisoned by organophosphorus (OP) pesticides every year. There is a pressing need for new affordable antidotes and in this context clonidine which has central effect ( $\alpha 2$ agonist) has been evaluated in the albino rats presenting with signs or symptoms of acute malathion poisoning. And compared with atropine for the acte malathion poisoning in albino rats.

Methods: This was a preclinical study conducted on albino rats of either sex weighing 100-150 grams were randomly divided into 4 groups (6/group). Malathion was given at the lethal dose of $54 \mathrm{mg} / \mathrm{kg}$ body weight (BW) by gavage to each group. Group 1: normal saline intraperioneal (i.p). Group 2: Post treated with atropine $1.5 \mathrm{mg} / \mathrm{kg} \mathrm{BW}$ (i.p). Group 3: Pre treated with clonidine $1 \mathrm{mg} / \mathrm{kg} \mathrm{BW}$ (i.p), 10 minutes priore malathion. Group 4: Pre treated with clonidine and post treated with atropine. The above groups were observed for straub tail, muscle fasciculation, piloerection, lacrimation, defecation/ urination; salivation, tremors, gasping and convulsion and were recorded at time $0,15,30$, 45 and 60 minutes after poisoning. The latency of onset of tremors, loss of righting reflex and tremors were recorded. Results were presented as percentage occurrence and Mean \pm SEM. Repeated measure one way ANOVA and Fisher's Least Significant Difference post hoc test for comparison between groups. Pvalue of 0.05 or less was considered for statistical significance.

Results: The central effects namely straubs tail and whole body tremors are significantly improved compared to control and atropine with clonidine group $(p<0.05)$. However convulsion shows improve in atropine alone and atropine with clonidine groups. The overall survival time has significantly increased compared to control and atropine and atropine with clonidine $(\mathrm{P}<0.05)$. Clonidine has not shown any effect on survival time.

Conclusions: Clonidine has some central protective effect in malathion poisoning. And it has not shown any effect on survival time. This issue needs further controlled studies.
\end{abstract}

Keywords: Atropine, Clonidine, Malathion, Organophosphate

\section{INTRODUCTION}

India being a predominantly agriculture based country, where pesticides are routinely used for farming. Malathion is one of the most widely used OP compounds in agriculture and public health programs to kill various pests. Malathion causes toxicity through hyperexcitation of the nervous system through its bio activated analog, malaoxon. ${ }^{1}$ The occupational, accidental and intentional (suicidal) exposure with OP is a leading public health problem in the developing countries. ${ }^{2}$ Most OP compounds exerts neurotoxicity via a common mechanism of action - binding to and phosphorylating the enzyme acetylcholinesterase (AchE). This causes AchE inhibiton and building up of neurotransmitter 
acetylcholine (Ach) in the central and peripheral nervous system synapses resulting in overstimulation at muscarinic and nicotinic cholinergic synapses. This overstimulation at muscarinic synapses results in hyper salivation, excessive lacrimation, miosis, intestinal cramps, vomiting, diarrhea, urinary and fecal incontinence and bronchorrhea. Overstimulation of nicotinic synapses results in muscle cramps, fasciculation, weakness, paralysis and pallor. Central nervous system effects include anxiety, restlessness, dizziness, confusion, ataxia, tremors, convulsion, agitation and respiratory depression etc. ${ }^{3,4}$

Approximately $35 \%$ of patients are acutely poisoned with OP compounds that require intensive care and mechanical ventilation. This is despite usage of conventional antidote treatment like atropine and oximes etc. ${ }^{5}$ Apart from this in the recent years have introduced new adjunct therapies such as sodium bicarbonate, magnesium sulfate, antioxidants, clonidine, bioscavengers like fresh frozen plasma or albumin have recently been tried. ${ }^{6,7}$ The effective use of clonidine in the treatment OP compound poisoning is quite uncertain, and further detailed evaluation is needed. ${ }^{8,9}$ Clonidine is a centrally active alpha-2 adrenergic receptor agonist which was traditionally used as an anti-hypertensive drug. Also the preventive effects of clonidine against the toxicity of soman, an organophosphorus warfare toxicant, have been reported. $^{10}$

In this context, clonidine which has central effect $(\alpha 2$ agonist) has been evaluated in the albino rats presenting with signs or symptoms of acute malathion poisoning (OP compound). Therefore, the present study was undertaken to examine and compare the antidotal effect of clonidine alone or combined with clonidine with that of atropine in albino rats which are acutely intoxicated with the malathion.

\section{METHODS}

The study was done in central animal laboratory of J.J.M. Medical College and research institute Davangere. Adult healthy albino rats of either sex weighing between $100 \mathrm{~g}$ $150 \mathrm{~g}$ were housed in polypropylene cages under hygienic conditions and were acclimatized for 2 weeks prior to commencement of the study. The rats were maintained on standard laboratory feed and water ad libitum throughout the experimental period. This study was done after obtaining prior approval from the Institutional Animal Ethics Committee. All animals were handled according to the guidelines of CPCSEA (committee for purpose of control and supervision of experiments in animals), Government of India.

\section{Experimental design}

24 albino rats of either sex weighing 100-150 grams were selected and randomly divided into 4 equal groups, containing 6 rats in each group. Pregnant female albino rats were excluded. Rats were dosed orally (gavage) with malathion at the lethal dose of at $54 \mathrm{mg}$ active ingredient $/ \mathrm{kg}$ body mass for each group for inducing the acute malathion poisoning. This dose was predetermined to induce cholinergic toxic manifestations in rats, and it represents approximately $50 \%$ of the oral LD50 of malathion in the rats. Malathion was diluted with distilled water to a concentration of $3.5 \%$. After malathion dosing, each rat was individually observed for the occurrence of signs of cholinergic toxicity. ${ }^{11}$

These signs included straub tail, muscle fasciculation, piloerection, lacrimation, Defecation/ urination; salivation, tremors, gasping and convulsion, and they were recorded at time $0,15,30,45$ and 60 minutes after malathion poisoning. The rats (6/treatment group) were treated intraperitoneally (i.p.) with either normal saline (control), atropine sulfate $(1.5 \mathrm{mg} / \mathrm{kg})$ or clonidine $(1 \mathrm{mg} / \mathrm{kg})$. The latency to onset of death, LRR and body tremors were recorded. Details of treatment schedule after acute malathion poisong are,

1. Group 1 (control): Normal saline i.p

2. Group 2: Post treated with atropine $(1.5 \mathrm{mg} / \mathrm{kg} \mathrm{BW}$ i.p) 5 minutes after malathion

3. Group 3: Pre treated with clonidine $(1 \mathrm{mg} / \mathrm{kg} \mathrm{BW}$ i.p) 10 minutes before the malathion

4. Group 4: Pre treated with clonidine (1mg/ kg BW i.p) 10 minutes before the malathion and post treated with atropine $(1.5 \mathrm{mg} / \mathrm{kg} \mathrm{BW}$ i.p)

Loss of righting reflex (LRR): The test is regarded as positive if the animal fails to right itself with all four feet on the floor within 15 seconds after being placed in a side position. The time of recovery and to righting or walking is recorded for each animal. If there was any doubt as to the reappearance of the righting reflex, the subject was placed gently on its back again and if it rights itself within one minute, this time is considered as the endpoint.

\section{Statistical analysis}

Statistical analyses were carried out on the data using Graph Pad Instat version 3.1 software. Results were presented as percentage occurrence and Mean \pm SEM. Repeated measure one way ANOVA was used for multiple comparisons followed by Fisher's Least Significant Difference (LSD) post hoc test for comparison between groups. P-value of 0.05 or less was considered for statistical significance.

\section{RESULTS}

$100 \%$ death occurred in albino rats that received 54 $\mathrm{mg} / \mathrm{kg}$ of malathion. All the symptoms of toxicity, time of onset and duration were observed and recorded. Malathion dosing in rats produced signs and symptoms of cholinergic poisoning which included straub tail, muscle fasciculation, piloerection, lacrimation, defecation, 
urination, excessive salivation, whole body tremor, gasping and convulsion. The percentage occurrence of above symptom is depicted in Table 1 . The occurrence of these signs in intoxicated rats ranged between $17-100 \%$. Intraperitoneal administration of clonidine $(1 \mathrm{mg} / \mathrm{kg})$ or atropine at $1.5 \mathrm{mg} / \mathrm{kg} 5$ minutes after the malathion dosing gradually and significantly decreased the occurrence of toxic manifestations in the rats over the 60minute observation period in compared to the saline and clonidine.

Table 1: The antidotal effect of clonidine and atropine on signs and symptoms of acute malathion poisoning.

\begin{tabular}{|c|c|c|c|c|c|c|c|c|c|}
\hline \multirow{2}{*}{$\begin{array}{l}\text { Time } \\
\text { (minutes) } \\
\text { after } \\
\text { antidote }\end{array}$} & \multicolumn{9}{|c|}{ Percent occurrence } \\
\hline & $\begin{array}{l}\text { Straub } \\
\text { tail }\end{array}$ & $\begin{array}{l}\text { Muscle } \\
\text { fasciculation }\end{array}$ & $\begin{array}{l}\text { Pilo- } \\
\text { erection }\end{array}$ & $\begin{array}{l}\text { Defecation } \\
\text { /urination }\end{array}$ & Lacrimation & Salivation & $\begin{array}{l}\text { Whole } \\
\text { body } \\
\text { tremmors }\end{array}$ & Gasping & Convulsion \\
\hline & \multicolumn{9}{|c|}{ Group 1 :Normal saline (control) } \\
\hline 0 & 83 & 67 & 100 & 50 & 67 & 50 & 67 & 17 & 33 \\
\hline 15 & 100 & 100 & 100 & 100 & 100 & 100 & 100 & 50 & 67 \\
\hline 30 & 83 & 83 & 67 & 67 & 83 & 50 & 100 & 0 & 33 \\
\hline 45 & 83 & 50 & 50 & 17 & 50 & 33 & 83 & 0 & 0 \\
\hline \multirow[t]{2}{*}{60} & 33 & 17 & 17 & 17 & 17 & 33 & 17 & 0 & 0 \\
\hline & \multicolumn{9}{|c|}{ Group 2 : Post treated with atropine } \\
\hline 0 & 83 & 50 & 67 & 33 & 33 & 33 & 50 & 17 & 17 \\
\hline 15 & 33 & 33 & 50 & 17 & 0 & 17 & 17 & 0 & 0 \\
\hline 30 & 0 & 0 & 0 & 0 & 0 & 0 & 0 & 0 & 0 \\
\hline 45 & 0 & 0 & 0 & 0 & 0 & 0 & 0 & 0 & 0 \\
\hline \multirow[t]{2}{*}{60} & 0 & 0 & 0 & 0 & 0 & 0 & 0 & 0 & 0 \\
\hline & \multicolumn{9}{|c|}{ Group 3: Pre treated with clonidine } \\
\hline 0 & 100 & 50 & 83 & 50 & 50 & 67 & 50 & 50 & 83 \\
\hline 15 & 50 & 33 & 83 & 50 & 50 & 50 & 83 & 33 & 67 \\
\hline 30 & 33 & 17 & 67 & 17 & 33 & 33 & 50 & 0 & 50 \\
\hline 45 & 17 & 17 & 50 & 0 & 17 & 33 & 17 & 0 & 33 \\
\hline \multirow[t]{2}{*}{60} & 0 & 17 & 0 & 0 & 0 & 0 & 0 & 0 & 17 \\
\hline & \multicolumn{9}{|c|}{ Group 4 : Pre treated with clonidine and post treated with atropine } \\
\hline 0 & 100 & 67 & 83 & 33 & 33 & 50 & 50 & 17 & 17 \\
\hline 15 & 33 & 33 & 50 & 17 & 0 & 33 & 33 & 0 & 0 \\
\hline 30 & 0 & 0 & 0 & 0 & 00 & 0 & 0 & 0 & 0 \\
\hline 45 & 0 & 0 & 0 & 0 & 0 & 0 & 0 & 0 & 00 \\
\hline 60 & 0 & 0 & 0 & 0 & 0 & 0 & 0 & 0 & 0 \\
\hline
\end{tabular}

Table 2: The effect of atropine and clonidine on malathion induced toxicity in albino rats.

\begin{tabular}{|llll|}
\hline Study Groups & $\begin{array}{l}\text { Loss of righting } \\
\text { reflex (seconds) }\end{array}$ & $\begin{array}{l}\text { Latency of onset of } \\
\text { body tremors (seconds) }\end{array}$ & $\begin{array}{l}\text { Survival time } \\
\text { (minutes) }\end{array}$ \\
\hline & Mean \pm SEM & Mean \pm SEM & $113 \pm 17$ \\
\hline Group 1: Normal saline(control) & $58 \pm 4$ & $115 \pm 12$ & $230 \pm 13$ \\
\hline Group 2: Post treated with atropine (positive control) & $98 \pm 7$ & $167 \pm 18$ & $133 \pm 25$ \\
\hline Group 3: Pre treated with clonidine (test) & $63 \pm 9$ & $133 \pm 10$ & $225 \pm 16$ \\
\hline $\begin{array}{l}\text { Group 4: Pre treated with clonidine and post treated } \\
\text { with atropine }\end{array}$ & $81 \pm 6$ & $158 \pm 9$ & 25 \\
\hline
\end{tabular}

The time to onset of LRR, latency of body tremors and survival time were depicted in Table 2 . The number of rats that died within 2-24 hours was recorded. The rats were considered dead when they failed to respond to agitation. Malathion induced death in acute poisoning was observed between 35 minutes and 230 minutes after single exposure. 


\section{DISCUSSION}

The purpose of this study was to observe and compare the preventive antidotal effects of clonidine and with that of atropine in the malathion poisoning. The malathion caused signs and symptoms of OP compound poisoning in albino rats by characteristic enzyme acethylcholinesterase (AChE) inhibition. This leads to the accumulation of acetylcholine at nerve endings (synapses), causing overstimulation and subsequent disruption of transmission at the both the central and peripheral nervous systems. Malathion poisoning manifests predominantly muscaranic effect and also effect nicotinic symptoms. ${ }^{12}$

Atropine therefore blocked the muscarinic receptors, thus eliminating the agonistic effect of acetylcholine on these receptors. This would explain the high percentage of survival observed in the atropine treated rats and clonidine along with atropine group compared to that of the control. Treatment with atropine however reversed the toxic effects of malathion on the poisoned rats and also confer some degree of protection on the rats organ atropine received groups. This finding is consistent with those reported by Yurumez et al, and that of Chedi and Aliyu. $^{13,14}$

Though the centrally acting $\alpha 2$-adrenergic receptor agonists such as clonidine can reduce Ach synthesis and release in pre-synaptic junction and has a protective effect against the centrally acting AchE, but in our study the rats which received only clonidine has shown significant $(p<0.05)$ improvement central effects only for straubs tail and whole body tremors compared to that of control and atropine with clonidine group. But our study results are similar with the study by Buccafusco and Aronstam 1986 that pre-treatment with clonidine protected against several of the centrally-mediated toxic effects of soman. ${ }^{15}$ Regarding the survival time, clonidine does not confer any protection on the albino rats, hence rats died in that group. ${ }^{12,16}$

Pre treatment with clonidine could postpone the occurrence of whole body tremor and the loss of righting reflex in poisoned rats. But it was not statistically significant.

\section{CONCLUSION}

The central effects namely straubs tail and whole body tremors are significantly improved compared to control and atropine with clonidine group $(p<0.05)$. However convulsion shows improve in atropine alone and atropine with clonidine group. The overall survival time has significantly increased compared to control and atropine and atropine with clonidine $(\mathrm{P}<0.05)$. But the clonidine has not shown any effect on survival time. This issue needs further controlled studies rather than drawing conclusions from a preclinical study.

\section{ACKNOWLEDGEMENTS}

The authors would like to thank Dr Siddappa Devaru Professor and former Head of the department and all the staffs of Department of Pharmacology of JJM Medical College Davangere for their help and support rendered at the various stages of the study.

Funding: No funding sources

Conflict of interest: None declared

Ethical approval: The study was approved by the Institutional Ethics Committee

\section{REFERENCES}

1. Al-Othman AM, Al-Numair KS, El-Desoky GE, Al Othman KYZA, Aboul-Soud MAM. Protection of $\alpha$ tocopherol and selenium against acute effects of malathion on liver and kidney of rats. Afr J Pharm Pharmacol. 2011;5(10):1263-71.

2. Gunnell D, Eddleston M, Phillips MR, Konradsen F. BMC Public Health. 2007;21(7):1-15.

3. KoeHe GB. Pharmacoogy and Toxicology of Organophosphates. In: Ballanty Be and Marre TC eds.Clinical and Experimental Toxicology of Organophosphates and Carbamates. Oxford: Butterworthl Heiman; 1992:40-46.

4. Zhou Z, Hu Y, Sun Y, Chen J. Protective Effect of Clonidine against toxicity of Organophosphorus Pesticides. J Occup Health. 2001;43:346-50.

5. Clinico-Epidemiological Characteristics of Patients Presenting with Organophosphorus Poisoning. Indranil Banerjee, SK Tripathi, and A Sinha Roy. N Am J Med Sci. 2012;4(3):147-50.

6. Balali-Mood M, Saber H. Recent Advances in the Treatment of Organophosphorous Poisonings. Iran J Med Sci. 2012;37(2):74-91.

7. Nurulain SM. Different approaches to acute organophosphorus poison treatment. J Pak Med Assoc. 2012;62(7):712-5.

8. Ramakrishnan K, Ramesh K, Sathyajith NG. Role of clonidine in organophosphate poisoning in children. $\mathrm{J}$ Indian Soc Toxicol. 2005;1:30-1.

9. Polwattage MSP, Jayamanna SF, Hettiarachchi R, Abeysinghe C, Karunatilake H, Dawson AH. A phase II clinical trial to assess the safety of clonidine in acute organophosphorus pesticide poisoning. Trials. 2009;10:73.

10. Magri V, Buccafusco JJ, Aronstam RS. Protection by clonidine from cardiovascular changes and lethality following soman administration in the rat: role of brain acetylcholine. Toxicol Appl Pharmacol. 1988;95:464-73.

11. Mohammad FK, Gada AMF, Shindala MK. Comparative antidotal effects of diphenhydramine and atropine against dichlorvos-induced acute toxicosis in rats. Vet archive. 2002;72(1):19-28.

12. Holy B, Oruambo F, Kenanagha B. Poor antedotal effects of copper and manganese on rats expossed to acute dose of dichlorvos. Ejpmr. 2015;2(1):290-303. 
13. Yurumez Y, Durukan P, Yavuz Y. Acute organophosphate poisoning in university hospital emergency room patients. Internal Medicine. 2007;46(13):965-9.

14. Chedi BAZ, Aliyu M. Effect and management of dichlorvos poisoning in Wistar rats. Bayero Journal of Pure and Applied Sciences. 2010;3(2):1-3.

15. Buccafusco JJ, Aronstam RS. Clonidine protection from the toxicity of soman, an organophosphate acetylcholine esteraseinhibitor, in the mouse. J Pharmacol Exp Ther. 1986;239:43-6.
16. Liu WF. A symptomatological assessment of organophosphate-induced lethality in mice: Comparison of atropine and clonidine protection. Toxicol Lett. 1991;56:19-32.

Cite this article as: Suresha KR, SantoshKumar M, Nagashayana. Preclinical study comparing the antidotal effect of clonidine with atropine for the treatment of acute malathion poisoning in the albino rats. Int J Basic Clin Pharmacol 2017;6:128-32. 